\title{
Surgical management of oesophageal foreign body using a minimally invasive oesophagotomy technique (MIOT) in an Indian Flap-shell turtle (Lissemys punctata) - a case report
}

\author{
Khan Sharun $^{1 *}$, Christo J. Francis ${ }^{2}$, and Ajith Pillai ${ }^{3}$ \\ ${ }^{1}$ Division of Surgery, ICAR-Indian Veterinary Research Institute, Izatnagar, Bareilly, Uttar Pradesh, India \\ ${ }^{2}$ Department of Gynaecology and Obstetrics, NTR College of Veterinary Science, Gannavaram, \\ Andhra Pradesh, India \\ ${ }^{3}$ Veterinary surgeon, District Veterinary Centre, Department of Animal Husbandry, Kollam, Kerala, India
}

SHARUN, K., C. J. FRANCIS, A. PILlAI: Surgical management of oesophageal foreign body using a minimally invasive oesophagotomy technique (MIOT) in an Indian Flap-shell turtle (Lissemys punctata) - a case report. Vet. arhiv 91, 221-226, 2021.

\section{ABSTRACT}

Accidental ingestion of fish hooks is common among turtles. Several techniques are available for retrieving fish hooks, ranging from simple non-invasive techniques to more complicated and invasive surgical procedures. The purpose of this case report is to document the successful surgical retrieval of an oesophageal foreign body (fish hook) using a minimally invasive oesophagotomy technique (MIOT) in an Indian Flap-shell turtle (Lissemys punctata). The adult male Indian Flap-shell turtle (Lissemys punctata) presented with a nylon thread protruding from its mouth. The dorsoventral radiographs confirmed the presence of a foreign body in the caudal oesophagus, just outside the coelomic cavity. After the induction of general anaesthesia, a sterile artificial insemination (AI) sheath was passed intraorally through the fishing line until it reached the hook. The fish hook was then retrieved by making a $5 \mathrm{~mm}$ incision at the point where the tip of the AI sheath was felt. The incision in the oesophagus and skin was closed in a routine manner. The turtle was kept in secure captivity for 20 days, following which it was released to its natural habitat. The oesophagotomy technique used in this case reduces the size of the incision considerably, thereby decreasing the possibility of postoperative complications.

Key words: fish hook; oesophagotomy; Indian Flap-shell turtle; Lissemys punctata; turtle

\section{Introduction}

Injuries associated with the ingestion of fishing hooks are common among turtles. Freshwater turtles are more prone to ingestion of baited fish hooks because of their opportunistic scavenging behaviour (STEEN et al., 2014). Ingested fishing hooks are commonly found lodged in the oral cavity or cervical esophagus (ORÓS et al. 2004). The prevalence of hook ingestion was found to be higher in larger turtles than smaller ones in some species of freshwater turtles (STEEN et al., 2014). Sometimes the swallowed hooks may be expelled without any surgical intervention (ORÓS et al.,

\footnotetext{
*Corresponding author:

Dr. Khan Sharun, BVSc. \& AH, MVSc., Division of Surgery, ICAR-Indian Veterinary Research Institute, Izatnagar, Bareilly, Uttar Pradesh, India, Phone: +91 7012649375 (IN); E-mail: sharunkhansk@gmail.com
} 
2004). However, this requires the animal to be retained in captivity for an extended period.

Ingestion of fishing hooks in turtles has been found to be associated with several digestive pathologies, such as stomatitis (ulcerative or necropurulent), oesophagitis (ulcerative or fibrinous), strangulation, intussusception, intestinal tears, and traumatic oesophageal perforation (ORÓS et al., 2004; DI BELLO et al., 2013). Ingestion of fishing tackle is also found to be associated with lead poisoning (BORKOWSKI, 1997).

Several techniques are available for managing fish hook ingestion that range from simple extrusion to more complicated and invasive surgical procedures (MORAES-NETO et al., 2003). If the fish hook is lodged in the cervical oesophagus, de-hooking can be attempted using the PVC pipe technique (JAEGER et al., 2003). In cases where de-hooking fails, surgical oesophagotomy can be performed by approaching the cervical esophagus through the ventral surface of the neck (HYLAND, 2002). Fish hooks lodged in the stomach can be accessed through the left axillary region, while hooks present in the intestine or pyloric area can be approached through the right or left pre-femoral fossa (DI BELLO et al., 2013).

The present communication aims to report the successful surgical management of an oesophageal foreign body (fish hook) using a minimally invasive oesophagotomy technique (MIOT) in an Indian flap-shell turtle (Lissemys punctata).

\section{Materials and methods}

An adult male Indian flap-shell turtle (Lissemys punctata), weighing 820 grams, was brought to the emergency clinic with a nylon thread protruding from its mouth. The turtle was found to be active and alert during the initial physical examination and was not showing any attempts at regurgitation. The skin of the turtle was found to be moist and the turgor was suggestive of normal hydration status. The oral cavity was examined to identify the origin of the nylon thread, but it was not possible to visualize the point of origin since it was further down, deep within the oesophagus. The foreign body was suspected to be lodged in the oesophagus since it was palpable outside the neck region. For further localization, a radiographic examination was advised. A dorsoventral radiograph of the turtle was taken from which a radio-opaque fish hook was identified in the middle third of the oesophagus just outside the coelomic cavity (Fig. 1).

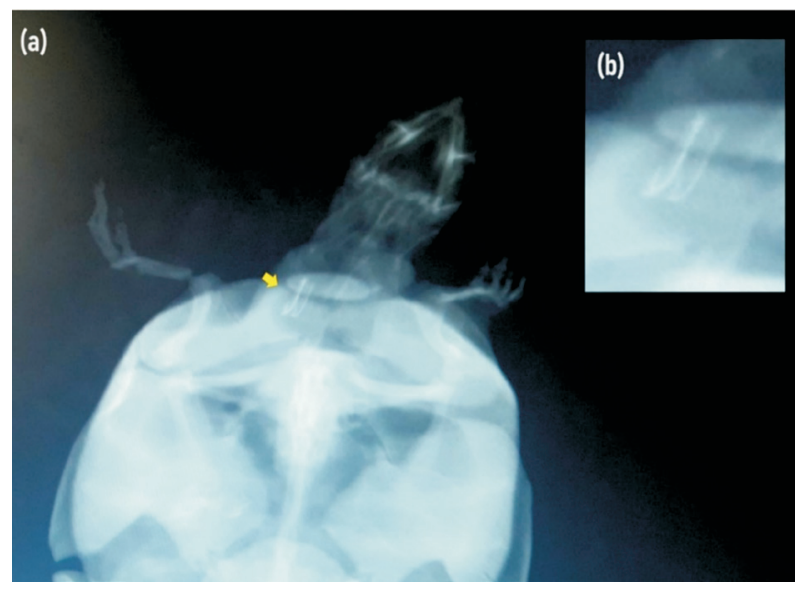

Fig. 1. (a) Dorsoventral radiographic image of the adult male Indian flap-shell turtle, showing the exact location of the foreign body within the oesophagus (arrow). (b)

The enlarged image is suggestive of a radio-opaque fishing hook.

The animal was given general anaesthesia using xylazine at the dose rate of $1.2 \mathrm{mg} / \mathrm{kg}$ body weight, and ketamine at $60 \mathrm{mg} / \mathrm{kg}$ body weight, intramuscularly as a single shot mixture. The depth of anaesthesia was monitored by analyzing the toe/ tail pinch response. Following the induction of general anaesthesia, the turtle was held ventrally with the neck extended to obtain sufficient access to the surgical site. A sterile, stiff and transparent artificial insemination (AI) sheath (outer diameter $4.5 \mathrm{~mm}$ ) was passed into the oesophagus so that the nylon thread passed through the central canal of the tube. The tube was then passed deep into the oesophagus until resistance was produced. Once it had reached the fish hook, the tube was then oriented ventrally so that the tip could be easily palpated from the outside. A small incision spanning $5 \mathrm{~mm}$ was made on the ventral skin of the neck, and the incision was further extended deeper into the underlying oesophagus. Simultaneously, pressure was applied on the plastic tube so that it slipped outside the oesophagus (Fig. 2, Fig. 3). 

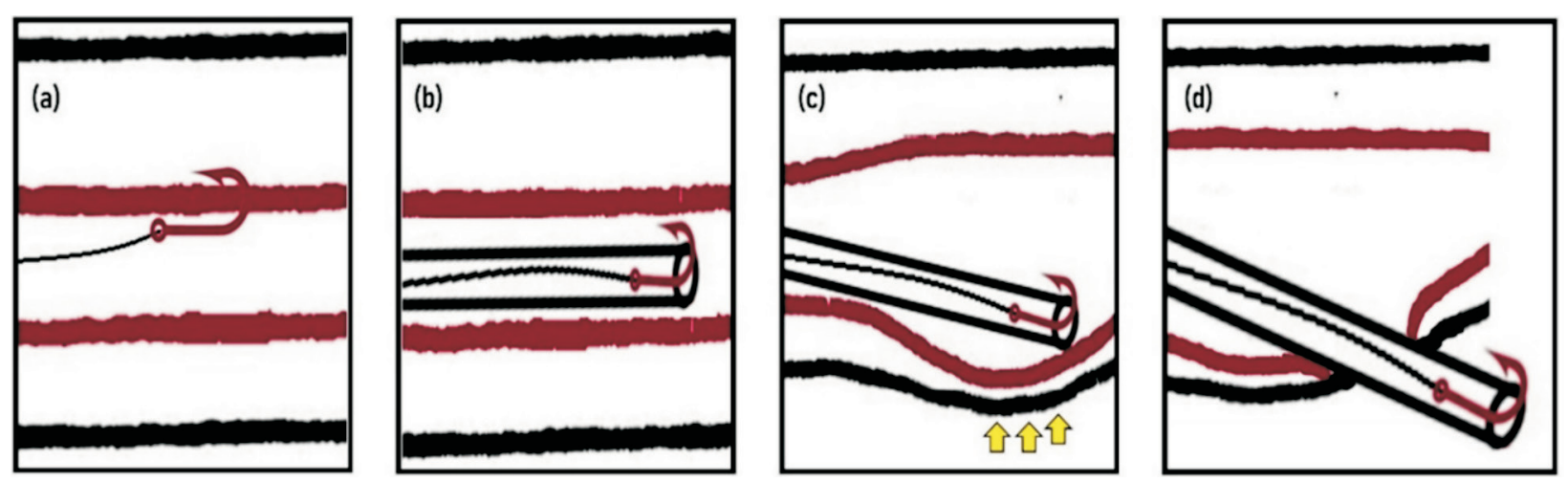

Fig. 2. Steps in the Minimally Invasive Oesophagotomy Technique (MIOT) (a) The fish hook that was found attached to the walls of the oesophagus. (b) A sterile AI sheath was passed in enclosing the nylon thread of the fish hook and slight caudal pressure was exerted to free the hook from the oesophageal wall. (c) The tube was then pressed against the skin to pinpoint the incision site (arrows). (d) An incision of $5 \mathrm{~mm}$ was made to exteriorize the AI sheath along with the captured fish hook.

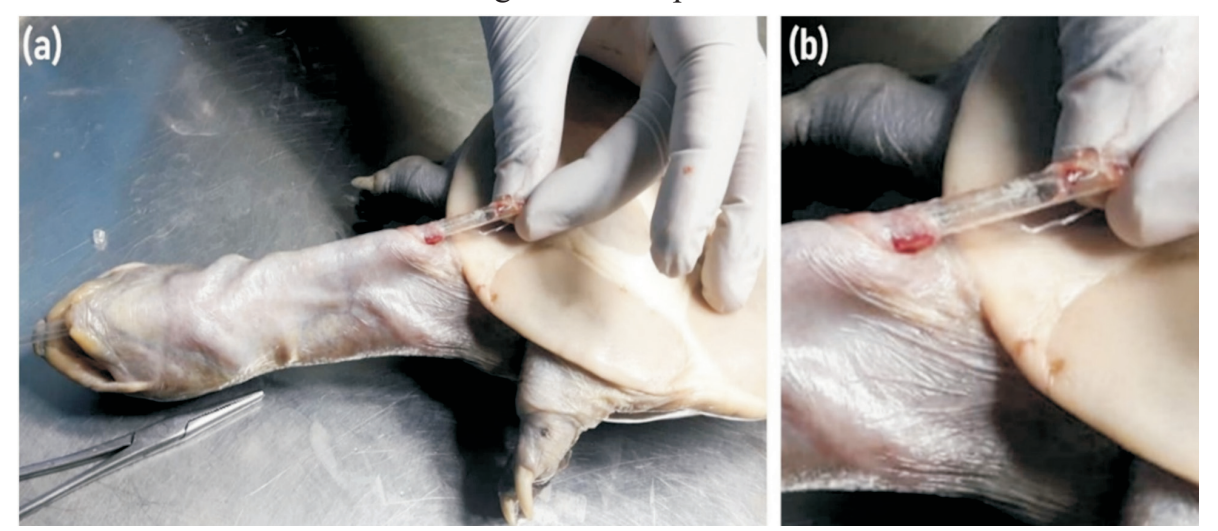

Fig. 3. (a) Passing the sterile rigid plastic tube through the nylon thread to determine the site of incision. Oesophagotomy incision made to recover the foreign body. (b) Removing the fish hook without causing any further damage.

The fish hook and the attached nylon thread were carefully removed from the tube (Fig. 4). The oesophageal incision was closed with two simple, interrupted sutures using polyglactin 910 (4-0). The skin incision was then sutured with monofilament nylon (2-0) in a simple interrupted pattern. Postoperatively, the animal was treated with amoxicillin-clavulanic acid at a dose of $10 \mathrm{mg} /$ $\mathrm{kg}$ body weight $\mathrm{q} 24 \mathrm{~h}$ via the intramuscular route for five days, along with the topical application of povidone-iodine ointment at the surgical wound. The caretaker was also advised not to let the turtle into any source of water for three days.

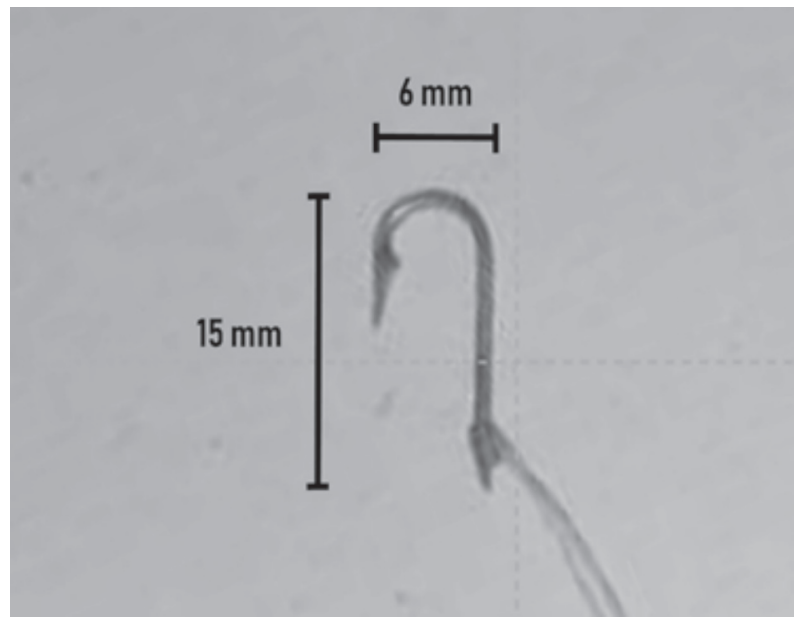

Fig. 4. The retrieved metallic fish hook was $15 \mathrm{~mm} \times 6$ $\mathrm{mm}$ in size 


\section{Results}

The whole surgical procedure was performed in less than 8 minutes. Therefore, neither additional anaesthetic boluses nor long-term monitoring of vital signs were required. The retrieved metallic fish hook was $15 \mathrm{~mm}$ x $6 \mathrm{~mm}$ in size (Fig. 4). The animal recovered uneventfully following postoperative antibiotic treatment. The skin sutures were removed on the $12^{\text {th }}$ post-operative day, following the complete healing of the skin incision. After surgery, the turtle was kept in a secure captive environment (modified fish tank with a small area of water, with a sand base and separate area for basking) for 20 days, following which it was released to its natural habitat from where it was captured.

\section{Discussion}

Recreational fishing poses a significant threat to freshwater turtle populations. High rates of hook ingestion are associated with mortality in freshwater turtles and might result in population decline (STEEN and ROBINSON, 2017). The majority of the available data report cases in which hooks have resulted in clinical conditions. However, this does not imply that hooks would not pass through the gastrointestinal system without causing pathologies. In an experimental study conducted in juvenile sea turtles with hooks lodged in the esophagus or stomach, about $50 \%$ of them were able to eliminate the hook in two years without any distress (ALEGRE et al. 2006). At the same time, they may also cause the perforation of the gastrointestinal tract, resulting in several consequences, such as: oesophagitis, regurgitation, stricture formation, cellulitis, and peritonitis, that can even lead to death (HYLAND, 2002). Other than the hook, the fishing line itself can act as a linear foreign body and cause intestinal perforation (BORKOWSKI, 1997).

According to the site of fish hook, various surgical approaches are available for retrieving the foreign body (DI BELLO et al., 2013). A fish hook lodged in the oral cavity can be retrieved successfully using an intraoral approach (SIVANARAYANAN et al., 2014). For this technique, the hook should be visible to facilitate easy retrieval. Once the fish hook passes the upper gastrointestinal tract, surgical retrieval becomes difficult (MINAMIKAWA et al., 2008). Monofilament fishing lines that reach the lower gastrointestinal tract may cause intestinal intussusception, that further results in necrotizing enteritis (ORÓS et al., 2004). Hooks lodged in the cervical esophagus can be accessed surgically via the ventral neck, while a supraplastron approach is required for hooks present in the intracoelomic part of the esophagus (DI BELLO et al., 2013). The transverse supraplastron approach is a less invasive technique that can be used for accessing the coelomic portion of the esophagus (JAEGER et al., 2003).

In the present case, MIOT was chosen since the fish hook was located in the cervical oesophagus, just outside the coelomic cavity. The technique that we used in this case is less invasive than the routine oesophagotomy that requires a large incision. However, MIOT cannot be performed in cases where the line extending from the hook is not protruding from the mouth or if an additional line emerging from the hook enters further into the gastrointestinal tract, as it may act as a linear foreign body. Although the endoscopic technique offers better visualization of the foreign body while retrieving it via the oral cavity, it is not possible in small turtles due to the disparity of instrument size. In addition to this, any attempt to retrieve metallic, rigid and sharp foreign bodies, such as fish hooks, via an intraoral approach with the help of endoscopic instruments may further damage the surrounding tissues.

In the present study, radiographic examination was not performed in the extended neck position. Therefore, we could not precisely identify the location (intracoelomic or oesophageal) of the hook. Furthermore, an additional radiographic view (lateral view) could have helped, especially when evaluating the position of the hook tip.

\section{Conclusions}

Hooks carrying bait to lure fishes can attract turtles in pond beds, and they are sometimes accidentally ingested. Being a sharp object, the ingested fish hook may become lodged in different parts of the digestive tract, resulting in several pathological conditions. A fish hook located within 
the oesophagus can be easily managed if it remains outside the coelomic cavity. The technique used in the present case can be considered as a minimally invasive method due to the very small incision size $(5 \mathrm{~mm})$ that can be closed with a couple of interrupted sutures. This technique will also reduce the post-operative healing time, thereby decreasing the chances of complications.

\section{Conflicts of Interest}

All authors declare that no commercial or financial relationships exist that could in any way lead to a potential conflict of interest.

\section{Acknowledgments}

All the authors acknowledge their respective Institute / University.

\section{References}

ALEGRE, F., M. PARGA, C. DEL CASTILlO, S. PONT (2006): Study on the long-term effect of hooks lodged in the mid-esophagus of sea turtle. Proceedings of the Twenty-sixth Annual Symposium on Sea Turtle Biology and Conservation, 3-8 April, Creta, Greece, pp. 234.

BORKOWSKI, R. (1997): Lead poisoning and intestinal perforations in a snapping turtle (Chelydra serpentina) due to fishing gear ingestion. J. Zoo Wildl. Med. 28, 109-113.

Di Bello, A., C. VAlAstro, D. FreGGi, O. R. LAI, G. CRESCENZO, D. FRANCHINI (2013): Surgical treatment of injuries caused by fishing gear in the intracoelomic digestive tract of sea turtles. Dis. Aquat. Org. 106, 93-102. DOI: $10.3354 /$ dao02641

HYLAND, R. J. (2002): Surgical removal of a fish hook from the oesophagus of a turtle. Aust. Vet. J. 80, 54-56.

DOI: $10.1111 / \mathrm{j} .1751-0813.2002 . t b 12834 . x$
JAEGER, G. H., M A. WOSAR, C. A. HARMS, G. A. LEWBART (2003): Use of a supraplastron approach to the coelomic cavity for repair of an esophageal tear in a loggerhead sea turtle. J. Am. Vet. Med. Assoc. 223, 353-355. DOI: 10.2460/javma.2003.223.353

MINAMIKAWA, S., Y. NAITO, K. SATO, Y. MATSUZAWA (2008): A case report of hook ingestion and expelling by a green turtle. Marine Turtle Newsletter 103, 11-13.

MORAES-NETO, M., D'AMATO, A. F., DOS SANTOS, A. S., GODFREY, M. H. (2003): Retrieval of an esophageal foreign body (fish hook) using esophagostomy in an olive ridley turtle, Lepidochelys olivacea. J. Herpetol Med. Surg. $13,26-28$.

DOI: $10.5818 / 1529-9651.13 .3 .26$

ORÓS, J., S. DÉNIZ, P. CALABUIG (2004): Digestive pathology of sea turtles stranded in the Canary Islands between 1993 and 2001. Vet. Rec. 155, 169-174.

DOI: $10.1136 /$ vr.155.6.169

SIVANARAYANAN, T. B., R. PATHAK, P. SANGEETHA (2014): Intraoral approach for retrieval of fish hook from flapshell turtle (Lissemys punctata). Intas Polivet 15, 178179.

STEEN, D. A., B. C. HOPKINS, J. D. VAN, W. A. HOPKINS (2014): Prevalence of ingested fish hooks in freshwater turtles from five rivers in the southeastern United States. PloS one 9, e91368-e91368.

DOI: 10.1371/journal.pone.0091368

STEEN, D. A., O. J. ROBINSON JR (2017): Estimating freshwater turtle mortality rates and population declines following hook ingestion. Conserv. Biol. 31, 1333-1339.

DOI: $10.1111 /$ cobi.12926

\section{SHARUN, K., C. J. FRANCIS, A. PILLAI: Kirurško liječenje stranog tijela u jednjaku minimalnoinvazivnom ezofagotomijom (MIOT) u indijske kornjače Flap-shell (Lissemys punctata) - prikaz slučaja. Vet. arhiv 91, 221- 226, 2021.}

\section{SAŽETAK}

Slučajna ingestija udice među kornjačama je česta. Postoji nekoliko tehnika za uklanjanje udice, od neinvazivnih do složenijih i invazivnih kirurških zahvata. Ovaj prikaz slučaja govori o uspješnom kirurškom uklanjanju stranog tijela iz jednjaka (udice) primjenom minimalnoinvazivne ezofagotomije (MIOT) u indijske kornjače Flap-shell (Lissemys punctata). U odraslog mužjaka uočena je najlonska nit koja je virila iz usta. Dorzoventralna radiografija potvrdila je prisutnost stranog tijela u kaudalnom dijelu jednjaka, malo izvan celomične šupljine. Nakon opće anestezije, sterilni kateter za umjetno osjemenjivanje uveden je kroz usnu šupljinu uz najlonsku nit do udice. Udica je uklonjena kroz 
K. Sharun et al.: Surgical management of oesophageal foreign body in an Indian Flap-shell turtle - a case report

rez od 5 mm na mjestu gdje se mogao napipati vrh katetera. Rez na jednjaku i na koži zatvoren je na uobičajen način. Kornjača je 20 dana zadržana u sigurnom zatočeništvu, nakon čega je puštena u svoje prirodno stanište. Ovaj oblik ezofagotomije znatno je smanjio veličinu reza, što je smanjilo mogućnost poslijeoperacijskih komplikacija.

Ključne riječi: udica; ezofagotomija; indijska kornjača Flap-shell; Lissemys punctate; kornjača 